\title{
Doktrin Ekonomi Kesejahteraan Ternyata Lebih Dekat Ke Ajaran Islam
}

\author{
Supardi
}

In Indonesia, social welfare denotes imperative-ideology, andit also constitutes constitutional demand. If modem economics tends to separate efficiency from ethics that judge wrong or right teaching, or fair or unfair doctrine, ethical economics force to unity both. Social welfare is the general continuity of welfare economics that contains ethical norms/values. In this respect Islamic economics building is universally, that means that this system actualize all human. Similar to Islamic economics, welfare economics as a economical system that will be applied in Indonesia including all Indonesian citizen, and economists have equal some opportunities to reach the goal of economy.

Kata kunci : Ekonomi,kesejahteraan, Ekonomi Islam

$\mathrm{P}$ embangunan nasional merupakan pengamalan Pancasila dan pelaksanaan UUD 1945 yang diarahkan pada peningkatan harkat, martabat dan kemampuan manusia serta kepercayaan pada diri sendiri dalam rangka mewujudkan masyarakat adil dan makmur baik materiel maupun spiritual. Negara Republik Indonesia menekankan kepada terwujudnya masyarakat yang adil dan makmur secara merata, bukan hanya sekelompok atau sebagian masyarakat tertentu saja. Dilihat dari tujuan pembangunan nasional maka negara RI menganut tipe negara kesejahteraan (welfare state).

Indonesia sebagai negara kesejahteraan dapat dilihat dari beberapa hal sebagai berikut: Pertama, sila ke lima dari Pancasila (falsafah negara) adalah Keadilan Sosial Bagi Seluruh Bangsa Indonesia. Ini berarti bahwa salah satu tujuan negara adalah mewujudkan kesejahteraan lahir dan batin yang merata bagi seluruh masyarakat Indonesia. Kedua, Pembukaan UUD 1945 (alinea IV) dikatakan bahwa tujuan pembentukan negara Indonesia adalah melindungi segenap Bangsa Indonesia dan seluruh tumpah darah Indonesia dan untuk memajukan kesejahteraan umum, mencerdaskan kehidupan bangsa dan ikut melaksanakan ketertiban dunia-yang berdasarkan kemerdekaan, perdamaian abadi dan keadilan sosial.

Pernyataan ini merupakan penjabaran dari kesejahteraan yang akan diwujudkan bangsa Indonesia. Bahwa negara mengemban empat fungsi pokok yakni protectional function, welfare function, educational function dan peacefulness function.

\section{Konsepsi Kesejahteraan Sosial}

Kesejahteraan sosial berdasar pada paham "demokrasi ekonomi" Indonesia, di mana."kemakmuran masyarakatlah yang 
utama, bukan kemakmuran orang-seorang". Hatta menegaskan hal ini sebagaimana dijelaskan oleh Swasono (2005:2). Di dalam konteks demokrasi ekonomi, kesejahteraan sosial Indonesia berdasar pada "hak sosial rakyat" (istilah Hatta), di mana "tiap-tiap warganegara berhak akan pekerjaan dan penghidupan yanglayak bagi kemanusiaan". Dari titik tolak ini, jelas bahwa penghidupan yang layak tidak terpisah dari pekerjaan.

Lebih dari itu, saat ini dalam ramairamainya kita bicara RPJM (2005-2009). Kesejahteraan sosial ditegaskan dengan istilah "meningkatkan Indonesia aman dan damai, Indonesia yang adil dan demokratis, meningkatkan kesejahteraan rakyat, meningkatkan perlindungan dan kesejahteraan sosial". Bagi Indonesia, kesejahteraan sosial menempati posisisentral dalam Kemerdekaan Indonesia. Di dalam UUD 1945ada pasal yang kita kenal sebagai "pasal ekonomi", yaitu pasal 33 , berada di bawah payung Bab XIV UUD 1945 yang berjudul "kesejahteraan sosial".

Dengan demikian itu maka posisi orde ekonomi Indonesia menjadi self-explanatory, menjadi jelas dengan sendirinya, bahwa kegiatan dan arah penyelenggaraan perekonomian nasional dengan segala statistika dan dinamikanya, harus berujung pada kesejahteraan sosial. Kesejahteraan sosial (societal welfare) merupakan kelanjutan yang lebih utuh dari pemikiran tentang ekonomi kemakmuran (welfare economic).

Ditilik secara historinya, Swasono (2005:3) menuturkan bahwa pemikiran dan doktrin Welfare Economics tentunya tidak bisa kita hindarkan dari masalah percaturan mengenai ilmu ekonomi, apakah ia merupakan ilmu "positif" atau "normatif", apakah ia ilmu "netral" (wertfrei, bebas nilai) sebagaimanan ditegaskan antara lain oleh
Max Webber (1881-1961), ataukah "mengemban nilai-nilai moral" (etika, pandangan hidup, filsafat, kepercayaan, perasaan hati).

Banyak titik-tolak pemikiran ekonomi dapat diambil untukmembahas masalah welfare (kemakmuran) dan welfare economics (ilmu ekonomi yang berorientasi kemakmuran). Swasono (2005: 8) mengambil contoh bahwa setengah abad yang lalu itu masih dengan tegas dikatakan oleh Boulding bahwa the subject matter of welfare economics, berbeda dengan lain-lain bentuk welfare, hanus didekati dari konsep harta atau "riches" ekonomi. Dengan pendekatannya ini ia lebih lanjut memperku-kuhkan konsepsi yang telah dikenal sebagai "social optimum", yaitu paretian optimality (optimalisasi ala Pareto dan Edgeworth), dimana economic efficiency mencapai social optimum bila tidak seorangpun bisa lagi menjadi lebih beruntung (better-off) tanpa membuat orang lain mengi (worse-off). Oleh karena itu dalam konteks ini pemborosan akan terjadi bila seseorang masih dapat menolong orang lain tanpa merugi. Namun efisiensi alokatif sumbersumber ekonomi ke tingkat optimal yang menjadi titik tolak pemikiran kaum klasik paretian ini (dan kemudian juga kaum neoklasik) ternyata tidak dengan sendirinya membawakan kesejahteraan sosial. Bagaimanapun juga pareto efficiency tidak membukakan kondisi untuk terbentuknya a good society dan tidak peka terhadap masalah distribusi.

Sementara itu Samuelson (1952) mengemukakan bahwa sebenarnya telah ada welfare economics baru yang tidak semata-mata berdasar kriteria ekonomi sempit, tetapi mengandung nilai-nilai etikal. Sebagai kebijakan distribusi pendapatan, economic welfare mengemban ethical precept (nilai-nilai etis normatif). 
Kemudian, apa yang disebut sebagai "new welfare economics" menurut Swasono (2005:10) mulai muncul menjadi “contemporary welfare economics" sejak Arrow mengajukan "impossibility theorem" yang ia kembangkan sebagai upaya menggabungkan preferensi-preferensi masingmasing anggota masyarakat menjadi preferensi sosial. Dari sini ditunjukkan secara teoritis bagaimana sulitnya menggabung dan mentransformasikan preferensi-preferensi individual menjadi preferensi sosial. Sebagaimana dikemukakan Swasono (1988) pada pidato pengukuhannya sebagai Guru Besar Universitas Indonesia, bahwa dalam kehidupan ekonomi masyarakat maka socialpreference interdependen dengan, tetapi bukan gabungan dari, preferences of individuals. Karena dalam pola interaksi sosial, individu-individu sebagai mahluk sosial akan berprilaku berdasar pada kaidah-kaidah nonekonomi yang lebih kompleks. Dengan kata lain, akan terjadi transformasi perilaku individu-individu dalam pola interaksi sosial, bahkan mungkin akan terjadi transformasi mind-set dan terbentuk suatu coherent collective mind and behavior. Jadi ada impossibility teoritikal bila bertitik-tolak dari preferensi-preferensi individual. Karena preferensi sosial ada'secara independen, individu-individu otomatis hidup bermasyarakat berdasar "rasa bersama."

Saat ini, setelah pemikiran Boulding, Reder dan Samuelson, welfare economics yang baru itu pun telah berkembang lebih jauh ke tingkat societal welfare di luar perfect individual liberty. Ini berkaitan dengan makin solidnya pandangan ilmu ekonomi sebagai ilmu moral (economics as amoral science). Dijelaskan oleh Swasono (2005:15), bahwa setelah Reder dan Samuelson melemparkan kritik terhadap welfare economics-nya Boulding, Baran (1957) menegaskan bahwa welfare econom- ics barunya Reder dan Samuelson pada masalah perlu tidaknya makna dan dimensi welfare di luar ekonomi an sich perlu. diperhitungkan. Baran secara kritis menunjukkan bahwa efisiensi ekonomi memang memberikan kontribusi kepada human welfare berdasar kriteria bahwa pada dirinya efisiensi ekonomi merupakan suatu orde-sosial-ekonomi yang hidup di dalam masyarakat. Namun bagi Baran, posisi welfare economics yang mengundang perdebatan teoritikal dan moral sesungguhnya terletak pada melencengnya ordesosial-ekonomi dari tujuan kehidupan ekonomi yang lebih utuh dan mulia, di mana hubungan lembaga-lembaga ekonomi dan sosial pada masyarakat kapitalis (yang mendewakan self-interest, perfect individual liberty, consumers'sovereignty dan stelsel laissez-faire) telah menghalangi tercapainya well-being masyarakat sebagai tujuan kehidupan ekonomi masyarakat yang utuh yaitu “... suatu masyarakat yang bebas dari keapatisan mental dan psikis (mental and psychic stupor) yang diakibatkan oleh ideologi kapitalis yang melumpuhkan masyarakat miskin...."

Baran adalah seorang ekonom sosialis yang bukan komunis, meskipun banyak mengikuti pandangan Karl Marx dālam pengutamaan kesejahteraan masyarakat yang berkemakmuran secara merata. Dalam pemikiran ekonominya, ia bersikap reformatif terhadap konvensionalisme "Smithian". Kaum ekonom sosialis di AS dan Eropa Barat (tidak selalu berarti komunis) inilah yang memberi penajaman awal pada pentingnya ilmu ekonomi keluar dari "Smithian" neo-classical orthodoxy, mendorong lahirnya pemikiran ekonomi strukturalisme yang menegaskan tentang bagaimana neo-classical economics ala "Smithian" semacam ini, yang self-interestbased dan competitive-based telah 
berkembang menjadi free-market economics. Kaum strukturalis menyoroti inherensi free-market atau market fundamentalism dengan perangai dasarnya yang tidak adil, brutal dan mengemban insting eksploitatori terhadap si lemah dan miskin. Kaum strukturalis muncul dan berkembang membelok dari pemikiran ekonomi pasarbebas dengan berbagai market-defects bawaannya. Kaum strukturalis menempatkan ilmu ekonomi pada peran normatifnya, menjelajahi komposisi dan interelasi antara para aktor ekonomi, sektor-sektor dan variabel-variabel ekonomi dalam rangka mengutamakan pemerataan kemakmuran, keadilan dan kesetaraan ekonomi. Kaum strukturalis menolak efisiensi ekonomistatik ala paretian optimum dan mentransformasinya ke dalam social optimum dinamis, di mana pasar-bebas dalam stelsel laissez-faire merupakan beban atau penghalang bagi tercapainya kesejahteraan disertai keadilan . dan kesetaraan sosial ekonomi masyarakat. Dimensi ekonomi pun tidak lagi tunggal (efisiensi ekonomi) tetapi juga berdimensi sosial politik.

Pandangan mengenai welfare economics, substansi dan dimensinya terus makin berkembang, diawali antara lain melalui buku Politics, Political Economics and Welfare (Dahl dan Lindblom, 1963, dalam Swasono, 2005:19). Dahl dan Lindbom menyayangkan istilah "Political Economy" tidak bisa digunakan saat ini tanpa memainkan triktrik mistik rohnya Adam Smith, David Ricardo. Dan Stuart Mill. Berikut ini mereka kemukakan dalam mengawali bukunya itu: Dalam teori formal ${ }_{2}$ ilmu politik dan ilmu ekonomi acapkali dianggap sebagai kerabat jauh dan tidak bisa begitúbicara satu sama lain. Dahl dan Lindblom berusaha mencari jalan untuk menyatukan aspek-aspek tertentu dari politik dan ekonomi ke dalam teori utuh yang konsisten. Pada wujud pertamanya, pertanyaannya terpusat ke dalam masalah etika daripada masalah ilmu. Kedua tokoh ini menegaskan bahwa tidak akan ada teori yang dapat menyatukan ilmu politik dan ilmu ekonomi kecuali teori ini mengeksplisitkan premis-premis sosiologi dan psikologi yang dikandung oleh masingmasing ilmu politik dan ilmu ekonomi. Akhirnya dari situ perlu dapat ditarik suatu "rational social action" untuk mencapai maksimisasi tujuan-tujuan good life, yang harus dicapai dengan perjuangan melalui kalkulasi rasional dan kontrol demokratis, yaitu untuk meraih nilai-nilai dasar "freedom", "equality", dan "progress". Makna welfare akhirnya bukan lagi sekedar tercapainya economic gain secara optimal belaka. Efisiensi berdimensi sosial, politik, psikologi dan filosofi, menjangkau tujuan humanisasi dan humanisme.

Dukungan terhadap perkembangan makna welfare tersebut kiranya sependapat dengan Welfare economics-nya Sen yang menuturkan, Welfare menjadi suatu gambaran dan proses rasional ke arah melepaskan masyarakat dari hambatan untuk memperoleh kemajuan (unfreedom) selanjutnya dengan mencari kriteria yang lebih luas (eclectic) diharapkan dapat lebih memberi makna well-being yang lebih mapan, dengan ukuran-ukuran (performance criteria) barunya seperti "tingkat kehidupan" (levels of living), "pemenuhan kebutuhan pokok" (basic needs fulfilment), "kualitas kehidupan" (quality of life) atau "pembangunan manusia" (human development). Demikian juga Etzioni (dalam Swasono, 2005:23), tiba-tiba saja muncul sebagai kritikus sosial luar biasa terhadap absurditas ilmu ekonomi. la bertanya diawal bukunya yang terkenal The Moral Dimensions: Toward a New Economics (1988) seperti dikemukakan di atas: "...Apakah manusia itu sekeluarga dengan kalkulator yang 
'dingin' dan takpeduli, yang masing-masing berusaha 'memaksimumkan' kesejahteraannya sendiri...Andaikata manusia memandang diri sendiri, baik sebagai anggota komunitas maupun sebagai individu yang mencari dirinya, bagaimana garis-garis ditarik di antara komitmen kepada orang banyak dan kepada dirinya... kita sekarang berada di tengah-tengah pertarungan paradigma..... Diungkapkan juga dalam bukunya yang lain The Limits of Privacy (1999), Etzioni menegaskan knitiknya terhadap individualisme ekonomi yang melatarbelakangi ilmu ekonomi neoklasikal dengan menyatakan bahwa privacy is a societallicence artinya privacy orang-perorang adalah suatu mandated privacy dari masyarakat. Kepentingan sosial bagi Etzioni, perlu lebih diperhatikan selain tujuan daripada ilmu ekonomi.

Dalam relevansinya dengan tulisan ini, Swasono (2005:21) mengungkapkan barangkali Hatta (negarawan), Baran (ideolog), Dahl dan Lindblom (ekonom), Myrdal (reformis), Sen (ekonom), dan Etzioni (sosiolog) yang melihat bahwa preferensi sosial itu ada secara independen, di aman individu-individu hidup di dalam suatu masyarakat sebagai kenyataan yang given.

\section{Kesejahteraan di Dalam Islam}

Di antara berbagai kenyataan sosial di Indonesia ialah, sebagaimana telah dijabarkan, kenyataan Islam sebagai agama rakyat terbanyak. Ini mengakibatkan adanya dua hal yang saling terkait dengan erat. Pertama ialah keharusan memperhatikan aspirasi mereka itu, yang secara kultural telah menjadi inti sistem kemasyarakatan kita. Adalah dalam perspektif ini kita harus memahami pandangan yang pernah dikemukakan Bapak Ismail Saleh, Menteri
Kehakiman, tentang "Eksistensi Hukum Islam dan sumbangannya terhadap Hukum Nasional". Juga dari sudut pandangan itu kita dapat mengerti pendapat Baharuddin Lopa bahwa peradilan di Indonesia di masa depan akan lebih banyak berdasarkan ajaranajaran Islam ("The- Jakarta post", Jakarta, 5 Oktober 1987, dalam Madjid, dkk, 1994: 579).

Sistem ekonomi Islam berbeda dari Kapitalisme, Sosialisme, maupun Negara Kesejahteraan (Welfare State). Berbeda dari Kapitalisme karena Islam menentang eksploitasi oleh pemilik modal terhadap buruh yang miskin, dan melarang penumpukan kekayaan. Disejajarkan dengan Sosialisme, Islam berbeda dalam hal kekuasaan negara, yang dalam Sosialisme sangat kuat dan menentukan. Kebebasan perorangan yang dinilai tinggi dalam Islam jelas bertentangan dengan ajaran Sosialisme. Namun, pada akhirnya ajaran Ekonomi Kesejahteraan (Welfare State) yang berada di tengah-tengah antara Kapitalisme dan Sosialisme memang lebih dekat ke ajaran Islam. Bedanya hanyalah bahwa dalam Islam etika benar-benar dijadikan pedoman perilaku ekonomi sedangkan dalam Welfare State tidak demikian, karena etika Welfare Stateadalah sekuler yang tidak mengarahkan pada "integrasi vertikal" antara aspirasi materi dan spiritual (Naqvi, 1981:80).

Paradigma ilmu ekonomi Islam secara signifikan berbeda dari paradigma ilmu ekonomi konvensional. Sekalipun terdapat banyak kesamaan, namun paradigma kedua disiplin tersebut berbeda secara radikal. Paradigmailmu ekonomi Islam lebih memberikan tekanan khusus kepada nilainilai moral, persaudaraan manusia, dan keadilan sosioekonomi (Chapra, 2001:48). Lebih lanjut, bahwa paradigma tersebut justru mengandalkan peran integral dari nilai- 
niiai dan lembaga-lembaga, pasar, keluarga, masyarakat, dan negara untuk menjamin falah atau kesejahteraan semua orang. Jadi penekanannya lebih kepada perubahan sosial melalui suatu reformasi pada tingkat individu dan masyarakat, dimana tanpa hal itu maka pasar dan negara hanya akan mengabadikan ketidakadilan. Karena penekanan pada keadilan inilah, para fuqaha telah meletakkan sejumlah qaidah ushul (legal maxim) yang dapat membantu merealisasikan kesejahteraan untuk semua dalam suatu cara yang seimbang dan adil. Kaidahkaidah tersebut dijelaskan (Chapra, 2001:59) sebagai berikut :

1. Suatu kerugian atau pengorbanan privat dapat ditimpakan untuk menyelamatkan pengorbanan atau kerugian publik, dan suatu maslahat yang lebih kecil dapat dikorbankan untuk merealisasikan maslahat yang lebih besar.

2. Suatu kerugian lebih besar dapat digantikan oleh kerugian yang lebih kecil.

3. Kemaslahatan mayoritas yang lebih besar harus di dahulukan daripada kemaslahatan minoritas yang lebih sempit; kemaslahatan publik harus dikedepankan daripada kemaslahatan privat.

4. Penghapusan kesulitan dan bahaya harus didahulukan daripada mendapatkan kemaslahatan.

5. Bahaya harus dihilangkan sejauh mungkin.

Penggunaan sumber-sumber daya yang paling efisien dalam ilmu ekonomi konvensional dapat didefinisikan menurut Optimum Pareto, sementara dalam suatu perekonomian Islam akan ditentukan berdasarkan maqashid. Setiap penggunaan yang menggagalkan realisasi maqashid harus dipandang sebagai kesia-siaan dan inefisensi. Sebagai contohnya, dalam ilmu ekonomi konvensional konsep Optimum Pareto membolehkan penghancuran kelebihan output jika hal ini memungkinkan pelaku bisnis menahan penurunan labanya tanpa membuat konsumen menjadi lebih buruk (kondisinya) karena naiknya harga. Namun, cara seperti ini tidak dapat diterima dalam paradigma Islam karena tidak hanya merusak sumber-sumber daya yang telah disediakan oleh Allah sebagai suatu bentuk amanah, melainkan juga menimbulkan ketidakadilan kepada konsumen. Meskipun usaha mempertahankan harga pada tingkat sekarang tidak dapat membuat konsumen menjadi lebih buruk, namun barang-barang itu dapat dibuat menjadi lebih bermanfaat jika kelebihan output tersebut tidak dihancurkan, harga akan turun atau kelebihan itu dapat dibagikan kepada orangorang miskin. Begitu juga, waktu dan energi yang digunakan untuk shalat dan berpuasa akan tampak sia-sia jika dipandang menunut kerangka materialisme, karena hal itu akan menyebabkan, meskipun tidak selalu, penurunan output sehingga menghambat maksimalisasi output dan laba. Namun, jika dipandang dari sudut kontribusi si kaya yang akan dapat menciptäkan character building dan peningkatan spiritual serta kesejahteraan manusia, maka shalat dan puasa sesungguhnya memilikj keunggulan positif. Barangkali karena alasan ini, dan alasan lain, seperti yang ditunjukkan sebelumnya bahwa salah satu qaidah ushul membolehkan penetapan suatu pengorbanan privat yang lebih sempit untuk mendapatkan kemaslahatan publik yang lebih besar.

Dengan demikian perilaku ideal dalam kerangka paradigma ini apabila kita telaah lebih lanjut dapat menjadi konsensus yang mendorong keseimbangan antara kepentingan individu dan sosial guna mengurangi ketidakadilan (Chapra, 2001:51). 
Menarik dicatat bahwa Ward mengusulkan bahwa para ilmuwan ekonomi mendasarkan berbagai pertimbangan kesejahteraan sosial pada warisan hukum dan proses legal Anglo-Amerika. Ward menunjukkan beberapa kesulitan yang harus berusaha diatasi, tapi menyimpulkan bahwa "... satu tujuan yang baik, secara moral atau dalam kaitannya dengan kelayakan prospektifnya'. Bisa dicatat bahwa kesulitan-kesulitan yang diramalkan Ward itu sebagian besar tidak ada dari yurisprudensi Islam karena kaum Muslimin percaya pada asal-usul Ketuhanannya (Zarqa, 1980: 16). Kemungkinan untuk menetapkan fungsi kesejahteraan sosial secara baik di dalam Islam merupakan perkara yang memiliki signifikansi amat besar bagi masyarakat, para pembuat kebijakan dan terutama bagi para ilmuwan dan ahli hukum Muslim. Mengenai petunjuk tentang signifikansi ini, lebih lanjut Zarqa (1980: 16) mengutip dari ulama Muslim yang terkenal, Muhammad Al-Mubarak, di dalam suatu konteks yang berbeda: "Produksi dan keuntungan (dalam sistem satu Islam) bukan tujuan atau alat. Kekuatan yang menggerakkan sistem yang berlaku adalah keuntungan, tetapi dalam sistem Islam, kekuatan itu adalah kesejahteraan manusia". Mendefinisikan kesejahteraan dari titik pandang Islam harus menjadi sine qua non bagi pembuatan berbagai rekomendasi Islam praktis mengenai aneka isu sosial atau ekonomi apa pun.

Berdasarkan indeks yang dikeluarkan UNDP (United Nations Development Progamme), Rabu (24/7/2002), Indonesia menduduki peringkat ketujuh dari sepuluh anggota Asean. Di bawah Indonesia, bertengger negara Myanmar, Kamboja , dan Laos. Sehingga, dapat diambil kesimpulan kesejahteraan Indonesia di tingkat internasional juga buruk. Masih menurut
UNDP, Indonesia menempati posisi 110 dari 173 negara, berada 'kalah' dari Vietnam (Republika, 25/7/2002), padahal bukankah Indonesia negeri yang alamnya sangat kaya?

Selama beberapa waktu terakhir, perhatian kita semua terpaku pada isu kesenjangan yang kian merebak. Beberapa tokoh mengeluarkan pernyataan yang menggambarkan seakan tingkat kesenjangan sedemikian buruk sehingga keadaan bangsa sudah tidak tertolong lagi.

Ada semacam kekhawatiran bahwa justru pernyataan-pemyataan, yang hanya mengobarkan kesenjangan itu, berbahaya karena bisa menyulut emosi bangsa yang sedang membangun. Akan jauh lebih arif sebenarnya, dan lebih bermantaat apabila kita semua dapat mengendapkan gejolak emosi barang sejenak dan melihat permasalahan ini dalam perspektif yang lebih objektif.

Dalam literatur ilmu ekonomi, agak sulit menemukan istilah kesenjangan. Terjemahan harafiah istilah itu dalam bahasa Inggris adalah gap. Sebagian besar ekonom memusatkan perhatian mereka pada upaya memahami gejala kemiskinan baik absolut maupun relatif dan menyusun perangkat kebijakan sosial-ekonomi untuk dapat mengentaskannya. Agar dapat kita cari dasar teorinya, mungkin konsep kesenjangan sebagaimana yang kita kenal itu disetarakan dengan inequality. Dengan demikian, equality dapat pula menjadi terjemahan pemerataan.

Dalam teori, equality pada umumnya dipilah menjadi tiga, yaitu: 1) equality before the law (perlakuan yang sama oleh penguasa), 2) equality of opportunity (peluang yang sama dalam sistem perekonomian), dan 3) equality of result (distribusi barang/ jasa yang sama). Apabila penulis tidak salah 
menangkap, maka debat terbuka selama ini lebih menitikberatkan pertiatian pada pilahan ketiga, yaitu distribusi

pemilikan harta dan kekayaan yang sama sebagai akibat keberhasilan pembangunan.

Equality ini memang tidak dibicarakan dalam ekonomi positif, yang lebih cenderung menyerahkan soal distribusi peluang dan barang pada mekanisme pasar semata. Ekonomi normatif, atau welfare economicslah yang membahas masalah distribusi secara lebih mendalam.

Ekonomi kesejahteraan merupakan bagian dari ilmu ekonomi mikro yang bersifat paling normatif. Ekonomi kesejahteraan berkaitan erat dengan alokasi barang dan sumber daya yang layak (feasible) bagi masyarakat dan membangun kriteria pemilihan di antara alokasi-alokasi yang mungkin. Oleh karena itu, masyarakat harus melakukan.pemilihan alokasi mana yang paling baik bagi dirinya. Jadi fokus utama di dalam ekonomi kesejahteraan terletak pada distribusi alokasi barang dan sumber daya. Praktek ekonomi itu seringpula disebut sebagai "ekonomi rakyat" yang bersifat moralistik, demokratik dan mandiri.

Swasono (2005: 35) mengemukakan bahwa dalam Pasal 33 UUD 1945 pengutamaan "hajat hidup orang banyak" menjadi titiksentral. Ketentuan konstitusional (Pasal 34 UUD 1945) bahwa "Fakir miskin dan anak-anak terlantar dipelihara oleh Negara" melengkapi dimensi social-welfare sesuai tuntutan kemuliaan manusia untuk menolong mereka yang tidak cukup berkemampuan produktif, suatu paham mulia yang mengemban humanisme dan melaksanakan humanisasi sebagai tugas intrinsik manusia beradab, melakukan kerelaan bercaritas, suatu kedermawanan emansipatif-filantropis sebagaimana dituntut oleh moralitas luhur dan etika agamaagama.

Ditegaskan oleh Pasal 27 (ayat 2) sebagai "hak sosial rakyat" (bukan sebagai belas kasih sosial) bahwa "Tiap-tiap warganegara berhak akan pekerjaan dan penghidupan yang layak bagi kemanusiaan". Bila di Amerika Serikat social welfaremerupakan cita rasa dan program kerja Kepala Negara, di Indonesia social welfare adalah suatu keharusan imperatif-ideologis, merupakan tuntutan konstitusional, yang dalam penyelenggaraan pemerintahan negara hingga sekarang, tidak dilaksanakan oleh Kepala Negara kita secara eksplisitsubstantif, tetapi sekedar secara marginalresidual. Hatta (juga Sukamo) adalah tokoh strukturalis awal yang melihat kese-jahteraan sosial tak terpisahkan dari keadilan dan kemakmuran pada tataran ideologi kerakyatan dan cita-cita kemer-dekaan nasional. Dengan demikian bagi para penyelenggara negara, kesejahteraan sosial yang bertumpu pada paham demokrasi ekonomi dan hak sosial rakyat untuk berperikehidupan layak sebagai manusia, haruslah merupakan doktrin atau pakem bagi wujud good govemance ala Indonesia.

Akhirnya, secara aksiologis Ekonomi Kesejahteraan perlu ditegaskan sebagai perekonomian yang bertujuan untuk mengentaskan masyarakat dari kemiskinan dan menghilangkan ketimpangan, kesenjangan, eksploitasi dan ketergan-tungan, melalui partisipasi rakyat dalam kegiatan ekonomi sehingga tercapai suatu kondisi masyarakat yang beradilan atau masyarakat adil dan makmur berdasarkan Pancasila. Karena itu rumusan normatif mengenai Ekonomi Kesejahteraan perlu disusun. Sebagaimana dikatakan oleh Bung Hatta, kita harus selalu ingat kepada pedoman normatif dalam kegiatan ekonomi, yaitu Pancasila yang perlu ditatsirkan secara sosial-ekonomi. 


\section{Penutup}

1. Pasal 33 ayat 1 UUD 1945 menyatakan bahwa "Perekonomian disusun sebagai usaha bersama berdasar atas asas kekeluargaan".bahwa perkataan "berdasar atas asas kekeluargaan'. Suatu konsepsi orde ekonomi yang berdasar paham "mutualism and brotherhood'. Paham tersebut dalam agama Islam kita kenal sebagai ukhuwah; selanjutnya sesuai dengan makna rahmatan lil alamin, membentukkan suatu world mutualism and brothemood, suatu persaudaran atau solidaritas yang berkeadilan dan berkesetaraan martabat antarseluruh manusia di permukaan bumi.

2. Ajaran agama Islam dalam perilaku ekonomi manusia dan bisnis Indonesia makin mendesak penerapannya bukan saja karena mayoritas bangsa Indonesia beragama Islam, tetapi karena makin jelas ajaran moral ini sangat sering tidak dipatuhi. Dengan perkataan lain penyimpangan demi penyimpangan dalam Islam jelas merupakan sumber berbagai permasalahan ekonomi nasional. Apabila ada keberatan dipakainya kata-kata Islam atau Pancasila untuk sistem ekonomi yang kita anggap tepat bagi Indonesia, barangkali yang paling masuk akal adalah menamakannya dengan Sistem Ekonomi Indonesia, mengacu pada kesepakatan Sumpah Pemuda 1928.

Sistem Ekonomi Indonesia adalah aturan main yang mengatur seluruh warga bangsa untuk bertunduk pada pembatasanpembatasan perilaku sosial-ekonomi setiap orang demi tercapainya tujuan masyarakat Indonesia yang adil dan makmur. Aturan main perekonomian Indonesia berasas kekeluargaan dan berdasarkan demokrasi ekonomi, yaitu produksi dikerjakan oleh semua untuksemua di bawah pimpinan dan penilikan anggota-anggota masyarakat. Dalam Sistem Ekonomi Indonesia yang demokratis kemakmuran masyarakat lebih diutamakan, bukan kemakmuran orangseorang. Setiap warga negara berhak memperoleh pekerjaan dan penghidupan yang layak sesuai harkat dan martabat kemanusiaan, sehingga dapat dihindari kondisi kefakiran dan kemiskinan.

\section{Daftar Pustaka}

Ahmad, Z., 1998, Kemiskinan dan Pemerataan Pendapatan (Seri Tafsir Al-Qur'an Bil llmi 09), Yogyakarta: Dana Bhakti prima Yasa.

Chapra, Umer. M., 2001, Masa Depan IImu Ekonomi (Sebuah Tinjauan Islam), Jakarta: Gema Insani Press.

Hasibuan, Sayuti, 1996, Ekonomi Sumber Daya Manusia (Teoridan Kebijakan), Jakarta: PT. Pustaka LP3ES Indonesia.

Madjid, Nurcholis dkk., 1994, Kontekstualisasi Doktrin Islam Dalam Sejarah, Jakarta: Penerbit Yayasan Paramadina.

Mubyarto, 1999, Reformasi Sistem Ekonomi, Dari kapitalisme Menuju Ekonomi Kerakyatan, Yogyakarta: Aditya Media.

1998, Sistem dan Moral ekonomi Indonesia, Yogyakarta: LP3ES.

Nagvi, Syed Nawab Haider, 1981, Ethics and Economics, An Islamic Synthesis, The IslamicFoundation, London. 
Topik: Keterpaduan Sektor Formal dan Informal Perkotaan

Qardhawi, Syeikh Yusuf, 1997. Pesan Nilai dan Moral dalam Perekonomian Islam. Jakarta: Robbani Press.

Rahman, Afzalur, 1995, (Terjemahan), Doktrin Ekonomi Islam, Yogyakarta: PT Dana Bhakti Wakaf.

Samuelson, Paul, 1973, Economics, International Student Edition, Singapore: McGraw-Hill Far Eastern Publishers (S) Ltd.

Schuler, Randall S., Susan E.Jackson, 1996, Manajemen Sumber Daya Manusia, Menghadapi Abad ke-21, Edisi Keenam, Jilid 1, Alih Bahasa Dwi Kartini Yahya, Jakarta: Erlangga.
Sudjiono, B., 2004, Ekonomi Berkeadilan Sosial: Menatap Masa Depan Indonesia, Jakarta: Lembaga Kajian Strategis Ekonomi \& Stabilitas Politik.

Swasono, Sri-Edi, 2005, Indonesia dan Doktrin Kesejahteraan Sosial : Dari Klasikal dan Neoklasikal sampai ke The End of Laissez-Faire, Jakarta: Penerbit Perkumpulan Prakarsa.

Zarqa, Anis, 1980, Islamic Economics: An Approach to Human Welfare, berupa Paper Dipublikasikan, Jeddah: King Abdul Azis University. 